\title{
Determining a Strategy for Sustainable Development of Local Identity: Case of Birgi (İmir/Turkey)
}

Kadriye (Deniz) Topçu*

\section{Abstract}

Today, it is difficult to retain and strengthen local character in the globalizing world. Showing the advantages of small towns and to strengthen their identities with focusing on 'small realities in a globalizing world" by increasing the value of local differences is an important subject in the global atmosphere. From this point, taking the advantage of Birgi's (Izmir/Turkey) having strong natural, man-made and cultural identity, this study aims to find out the most appropriate planning strategy for the sustainability of Birgi's (İzmir-Turkey) local character and identity which was selected as a case study. This study made some on-site observations for establishing the existing local identity potentials of Birgi. After these observations, within the scope of the study, first of all, strengths, weaknesses, opportunities and threats (SWOT factors) of the settlement were identified. Additionally, to determine the most appropriate planning strategy, a numerical SWOT analysis called A'WOT analysis which is the combination of Analytical Hierarchy Process $(A H P)$ and SWOT analysis was used. Then, identified SWOT factors prioritized by an expert group (35 person) using A'WOT analysis. After finding general and local priority values of SWOT factors, four planning strategies were displayed by using TOWS matrix. Then, the most appropriate strategy among these planning strategies was chosen
Keywords: Sustainability, local identity, $A^{\prime}$ WOT analysis, TOWS matrix, Birgi

*Asst Prof. Dr. Faculty of Architecture and Design, Konya Technical University, Konya, Turkey. E-mail: kdeniztopcu @gmail.com Orcid ID: http://orcid.org/0000-0003-45301969 
according to their priority values. In conclusion, it was found that "Entering to Slow City Movement" planning strategy is the most appropriate and important strategy between prioritized planning strategies for the sustainability of Birgi's local identity.

\section{INTRODUCTION}

Due to fast changes in technology and the shift from local to a globalized world, cities are forced to compete with each other in order to be an attractive tourist destination, workplace, cultural place and much more (Kotler and Gertner, 2002). In this globalizing atmosphere, today, it is difficult to retain and strengthen local character. There are many related reasons why local characters in many locations have disappeared over the last 70 years within this competitive atmosphere. One effect of disappearing local character is an increasing homogeneity between cities and societies (Featherstone, 1993) or homogenization of urban identity in the globalizing world. The scale and speed of development carried out by organizations operating nationally or globally, producing placeless, non-place and similar commodities in the name of efficiency. You can find a typical, similar building in everywhere. Modern development and/or redevelopment, unfortunately, usually aim at the efficiencies of large-scale construction and maximum use of site. Accordingly, the design is oriented towards creating a monotonous, standard 'any place' image rather than enhancing a sense of heritage and tradition that builds citizen identification and pride (Appleyard \& Jacobs, 1982; Oktay, 1998).

As the world has become universally more similar, the desire for uniqueness of place has grown and remains strong today. For this reason, it is obvious that the sustainability and livability of authentic settlements which embody strong urban identities is rather important. So, it is an important necessity that they should be undertaken rather carefully. In other words, analyzing sustainability of local identity as a case study is more important today (Radstrom, 2011). However, smaller urban areas which have a local identity generally do not receive as much attention, and frequently find themselves attracted to foreign 'solutions'. Therefore, the local sense of place, in many locations, is at risk if it is not properly sustained.

Showing the advantages of small towns and to strengthen their identities with focusing on 'small realities in a globalizing world" by increasing the value of local differences is an important issue (Miele, 2008, URL, 2). It is about protecting the environment, about promoting local goods and produce, and about avoiding the 
"sameness" that affect too many towns in the modern world in a negative way.

By these above concerns, Birgi (İzmir/Turkey) which has a strong authentic and local identity and did not live the globalizing effects was studied in the scope of the study. The aim of the study is to find the most appropriate strategy for the sustainability of Birgi's local identity. To find the most appropriate strategy and to sustain the local character, first of all, spatial characteristics and local identity of Birgi, its potentials and problems were displayed. Secondly; strengths, weaknesses, opportunities and threats (SWOT) of Birgi were identified under the present circumstances and within the perspective of historical background. Later on, to systematically evaluate the SWOT factors and make them commensurable as regards their intensities and to improve the quantitative information basis, a hybrid method called 'A'WOT analysis' was used. In this method, in which SWOT and AHP are used together, the importance of SWOT groups (strengths, weaknesses, opportunities and threats) and the priorities of each SWOT factors in each SWOT groups can be quantified. In this way, they can be measured and set in order.

A total of 35 experts (urban planners and urban planner candidates) who have previously experienced Birgi, graded the determined SWOT factors. With this analysis, according to the priority values, four alternative planning strategies for Birgi were developed. Later on, the most appropriate strategy for the sustainability of Birgi's local identity was chosen by using the same prioritization process and TOWS matrix.

\section{LOCAL IDENTITY AND ITS COMPONENTS}

Identity is one of the essential goals for the future of good environment. Lynch (1981) defines identity as 'the extent to which a person can recognize or recall a place as being distinct from other places'. People should feel that some parts of the environment belong to them. The urban environment should be an environment which encourages people to express themselves, to become involved, to decide what they want and act on it. To attract and hold people, an urban environment should cultivate a strong, independent image for which people can develop strong identification and affection (Appleyard and Jacobs, 1982; p.11; Oktay, 1998; p.17).

Identity is a process, not a found object. It may be linked to the trail left by civilization as it moves through history. The trail is the culture, or identity of that civilization (Abel, 1997). In this point, it can be said that urban identity is an historical process which is 
formed by the different overlapping cultural layers and can be formed and change in the course of time (Tekeli, 1990). Therefore, the urban environment has to be considered from a historical perspective to understand the important periods regarding the settlement, not only by understanding historically significant buildings, but rather through the evolution of the local urban context, with respect to human activity, built form, and nature (Aly, 2011). Therefore, to understand the identity of an environment, we should know the complex interaction of natural, social and built elements.

Local identity is a reflection of all the local people's traditions, culture, aspirations grouped together. It reflects their needs, their successes, their failures and their future (Aly, 2011). The most evident social indication areas of traditional Turkish cities' local identities are 'mahalle's (neighborhoods). 'Mahalle' is the smallest built environment of the city and generally has mosque, primary school, bath, külliye, grocery, coffee house, open and green areas and playgrounds. The people of these areas are connected with each other by strong relationships.

However, today, parallel to the changing life styles, these areas started to evolve into only the accommodation and housing units from the symbol of the social areas. Neighborhood and social relations of these areas are not much more seen today. This situation is one of the crucial problems of modernization, individualization and alienation process. In this point, Birgi settlement which selected as a sample area is rather important example in terms of being authentic place, sustaining its social pattern and its former traditional 'mahalle' understanding.

In addition to social structure, natural environment conditions of the settlement (i.e. topographical situation, geographical data, climate, existing water resources, flora, geological structure etc.) are also effective on forming local identity. Land structure affects local identity whether through the settlement form or positioning of the buildings. Natural and topographical data are important inputs because these data give an opportunity for determining structure types, location of the structures and shape of the structure groupings (Ayan, 1985; Ocakçl, 1993; Deniz, 2004). Besides, architectural (i.e. building colors, materials, roof types, orientation of the buildings etc.) and planning scale properties (i.e. narrow or wide streets, green pattern etc.) are generally produced based on climate data. Accordingly, it can be said that natural data is actually one of the important constituents of the local identity and affects the identity of built environment directly. 
Surely, the other important factors of local identity is built environment (man-made environment) which people shape and mould with his/her own culture. Built environment that consists of urban occupancies (structures, image elements etc.) and urban vacancies (streets, open and green areas, squares etc.) generally express its users' ideas, thoughts and ideals (Hough, 1990). According to Ocakçı and Southworth (1995), to establish local identity in built environment, presence, location and meaning factors are more important. Similarly, John Montgomery (1998) stated that the stable physical setting (form), the activities, and the meaning constitute the three basic elements of the identity of places. According to him, the first two of these elements can probably be apparent, but the component of meaning is much more difficult to grasp. Much more focus must be put on the 'sense of place' which is the aura and impression of the place. Meaning and character have more than a purely visual or spatial dimension, and they cannot be instantly achieved by the implementation of a new urban design scheme. So, meaning of a place is a process which is shaped and completed with culture and life experiences of its users. In this point, it can be said that if socio-cultural environment which consists of traditions, customs, life styles, demographical and institutional structure (Ocakçı and Southworth, 1995) passes through to build environment, we can talk about 'sense of place', 'place identity' or 'local identity' concepts.

Sustainability of local identity can be achieved by continuity of color, texture, material, floor covering, scale, façade details, lightning, vegetation and silhouette (Lynch, 1960) of the settlement. In this perspective, in order to speak of identity, it probably would not be wrong to say that continuity of certain conditions that must exist in the community should be provided (Öngül, 2012). So we should know the certain conditions of the area to find the most appropriate strategy for sustainability of Birgi's local identity.

In these senses, first of all, Birgi's historical periods and breaking points that affect its local identity were investigated and then existing identity conditions which were classified as the following aspects were analyzed;

- Social environment aspect (Neighborhoods 'mahalle')

- Built environment aspect (urban fabric, architectural and symbolic values)

- Natural environment aspect (topographic and environmental sources) 
After analyzing existing identity conditions, problems and potentials of the area were displayed to develop a basis for SWOT analysis.

\section{A GLIMPSE ON LOCAL IDENTITY OF BIRGI}

\section{Historical Background and Breaking Points of Birgi}

Birgi, which was established for the purpose of defense, on a hillside on the coast of the lowland, being in a convenient position for castle construction (Bozoğlu, 1998) is at the height of $400 \mathrm{~m}$. above the sea level and located at the edge of the Küçük Menderes River (Kaistros) which is irrigated by a large and fertile plain (Figure 1). The population of the settlement is 1932 in 2017 while it was 2214 in 2013 (URL 1).

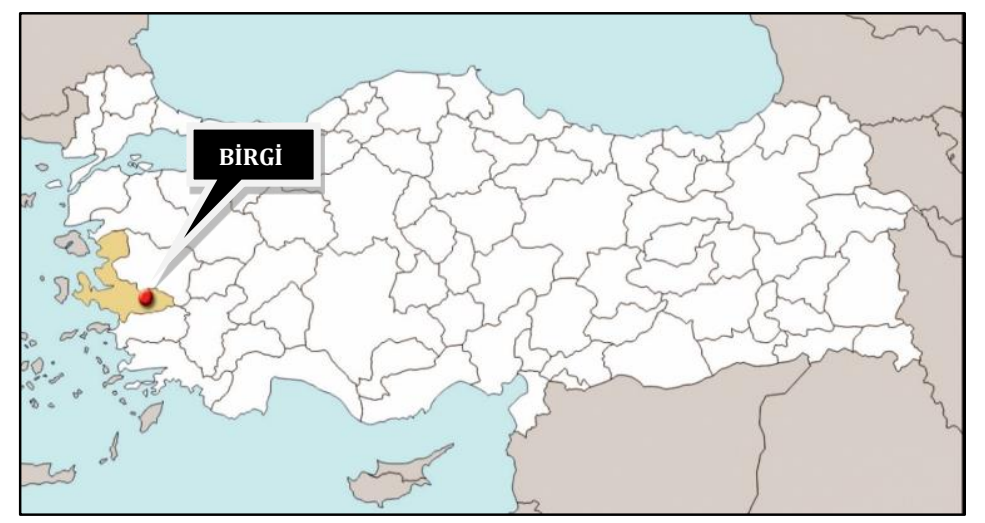

Figure 1. Location of Birgi in its vicinity and Turkey
At the intersection of civilizations in Western Anatolia, Birgi, since ancient times, has always known and been open to settlement due to its geographical location, its underground-surface richness, its proximity to water resources and its being a natural defense space. The name of the settlement was 'Dioshieron', meaning 'the holy place of Zeus' in antiquity, 'Christopolis', meaning 'the city of Jesus' in the Medieval period, 'Pyrgion' meaning 'fortress and bastion' in the Byzantine period and "Birgi" in the hands of the Turks. The settlement was under the rules of Lydia, Persia, Greek, Roman, Byzantine, Aydınoglu, Ottoman and Republican period respectively.

It was located on the trade axis; from Ephesus to Tire, from Tire to Sardis which was the capital of Lydia. Therefore, at the antiquity, especially in Lydian period, Birgi was rather an important city. In Byzantine period, it was an episcopal center for a while (1193-1199). It had lived its brightest period during the Aydınoğlu period (it has captured in 1308). In this period, Birgi was in a very good economic situation and had become a science and cultural center as a capital and equipped with many valuable architectural works that reflect the power and splendor of the Aydınoğulları era (caravanserais, darussifas, public soup kitchens, fountains, bridges etc.) (Yavuz, 1980; Anonymous, 2001; Tanaç, 
2001; Gençsoylu, 2009, Altınoluk, 1997). Briefly; Birgi was an important religious and cultural center from the first era to the Ottoman period.

It is known that the settlement of Birgi, which was captured by the Ottomans in 1390, retained its former power of structural character in the period of its first domination (Tanaç, 2001). The settlement between the years 1425 and 1575 was the second largest city of Aydın Province and one of the largest cities of Western Anatolia. In the 17th century, it is one of the largest and most productive of the province of Aydın, and is at the top of the list for the production of its land and the population living on it. In these periods, leather, silk production and weaving were made in the settlement. On the other hand, with the Ottomans reestablishing the region after the Fetret period, Birgi completely lost its old capital image. Especially after the late 17th century, it fell into a period of collapse, and suffered a massive loss of population. Towards the end of the Ottoman period; the development of İzmir and Aydın and the formation of the new trade axes away from Birgi caused Ödemiş to develop and to replace Birgi (Yavuz, 1980; Anonymous, 2001; Tanaç, 2001; Altınoluk, 1997; Gençsoylu, 2009).

There are many breaking points for beginning to decline and entering to the collapse process of Birgi settlement, especially after the change in the role of the settlement that the Ottoman Empire gave. Natural, physical and social breakpoints which cause the regression of the settlement and slow down the developmental acceleration of the settlement can be listed in the most general form as follows:

- $\quad$ Plague diseases $(1560,1865)$

- Earthquakes in various periods (1653, 1846-1850, 1944, 1994). These earthquakes caused considerable damage in various parts of the settlement or in important monumental structures (Altınoluk, 1998) (i.e. damage in Great Mosque and some buildings).

- $\quad$ The flood caused by the flooding of Birgi Stream in 1939 caused great damages in the region (Bozoğlu, 1996) (i.e. Derviş Ağa Külliye focused major destruction).

- Suffered great damage as a result of the fires in the occupation while Greek invasion between 1919 and 1922 (Altınoluk, 2001; Bozoğlu, 1996).

- $\quad$ Since the 18th century, the social life of the society began to differentiate. The railway trade, which was the technology of that period, entered to the differentiated life. With these changes, the topographic features which contributed to the 
development of the settlement, began to prevent the development of the city, caused to be kept hidden and protected. As a result, the Birgi economy had also decreased. For these reasons, the settlement could not grow and the trade axis gradually shifted to other places (Tanaç, 2001).

- In the mid-nineteenth century, after the reforms, the economic decline in the business area, made Birgi to be weak economically. Therefore, outward migration and decrease in population could be seen within the settlement (Tanaç, 2001).

- The disappearance of the religious center identity because of the closure of the Imam-i Birgivi Madrasah (16th century) (1925), which made Birgi a center of religion (Tanaç, 2001).

The above-mentioned developments, which can be described as breakpoints and have great effects on the spatial structure of the settlement, have very important effects in shaping Birgi's current structure. In general, it has seen that the 20th century was an unfortunate period for Birgi because of many earthquakes, floods, wars and Greek invasion. For Birgi, this situation began to improve only after the 1960s. In these years, historical artifacts were repaired and the whole settlement was declared as "protected area". With the legal facilities provided, historical urban areas were covered within the scope of the protected area, oriented to the protection of structure groups instead of the individual structures. And, the unconscious destruction of structures had been tried to be prevented. These developments were rather important steps for protecting Birgi's local identity and for making it alive.

Briefly, it can be said that the settlement of Birgi is one of the few settlements with a history that has managed to preserve its existing identity as much as possible, even though it has been exposed to many disasters in the historical process.

\section{Evaluating Local Identity of Birgi by Social Environment} Aspect; Neighbourhoods-'mahalle'

The 'neighborhood' concept (mahalle-in Turkish), which is the most significant physical and social building block of the spatial characteristics and local identity of the Turkish city, gives a unique identity to the settlement of Birgi in terms of providing unity in social life. The neighborhoods (Camii Kebir, Demirbaba, Kurtgazi and Cumhuriyet) within the structure of Birgi settlement are not only physical formations but also living spaces where values such as unity, togetherness and solidarity are kept alive. These living spaces, where neighborhood relations and social life are connected with strong bonds and still maintain the traditional 
way of life, are united with the physical spaces and constitute the original identity of Birgi. The social life as well as the physical environment is still hidden in today's conditions, therefore the originality of Birgi settlement further increases.

The physical formation of the neighborhood also has a number of functional elements that support the preservation of social life (outdoor bakeries within the neighborhood, fountains etc.). These types of elements made the social relations alive and provide togetherness, and the sustainability of social life. Human-scale streets are living spaces that allow neighborhood relations to be intensively kept alive.

The people of Birgi is rather hospitable to local and foreign tourists, open minded to new ideas, thoughts and movements. Therefore, many festivals, activities can be made and sustained in its active social life.

In addition to neighborhood life in the formation of social identity, some habits such as dowry preparations of young girls, folk dances, folk songs, henna nights, weddings, street conversations, hospitality, solidarity, various customs and traditions and coffee chats continue to a certain extent (Eruzun, 2000). These kinds of habits are important data for Birgi's social identity.

\section{Evaluating Local Identity of Birgi by Built Environment} Aspect; Urban Fabric, Architectural and Symbolic Values

Birgi is a typical "Turkish city" with its streets, religious buildings and traditional houses. Many descriptions had been made about Birgi within the historical process. For example; Charles Texier described Birgi as "...beautiful trees shade the streets, houses painted in many colors create a rich landscape for Birgi...", Weber mentioned about Birgi that the river which passes through the settlement is the most important value of it and the medieval bridge over the river gives a very nice view with the old plane trees. And, Evliya Çelebi described Birgi as "...invisible from the gardens and vineyards..." (Altınoluk, 2007).

Birgi which has skillfully placed on three-dimensional terrain by using the topographical data of the land in the most correct way, has an integrated identity with its houses with courtyards in terms of architectural viewpoint (Tanaç, 2001). According to the observations, the original or slightly altered examples in the settlement seem quite high. Birgi has many officially registered buildings and monumental structures. This is also an indication of the originality of the settlement.

The old traditional pattern of Birgi is seen in the Camii Kebir district, where the old texture is preserved by getting rid of the 
fire. This neighborhood with its urban features and housing typology carries the Turkish City character more than the other neighborhoods and is noteworthy for the stone or soil dead end streets that are positioned according to the topography (Bozoğlu, 1996).

Archaeological richness of the settlement is seen within the Demirbaba district. On the stone walls near the roof, one can see some cypress, pomegranate and sun motifs which are the symbols of Birgi. These motifs were made by using tile and white flint stones and represent abundance. This neighborhood also offers an original perspective and identity to the settlement with its unique texture (Altınoluk, 1998).

Cumhuriyet district, which is the historical-traditional commercial center of the settlement, reconstructed in the early 20th century (in the 1925 's), as the Greek army destroyed the district by the fire during the withdrawal process (Bozoğlu, 1996; Tanaç, 2001). Therefore, the historical value of this district is weaker when compared with the other districts of the settlement. However, in the process of reproduction of this district, it is a very important and sensitive attitude in order not to act against the traditional character, to protect the urban identity and to revive it (Eruzun, 2000). The streets in this district are in a geometric order and there is no dead-ends (cul-de-sacs) (Bozoğlu, 1996; Tanaç, 2001).

Kurtgazi district which is located on the western slope of the settlement is forced by the paths since they are located perpendicular to the slope (Tanaç, 2001). It has a texture that can be considered as original but has lost value in terms of quality. In addition, the fact that the topographic structure is quite steep in this region has brought the structures parallel to the slope and this situation has added a unique identity to the settlement in terms of urban view.

The houses in the Birgi settlement, which has a homogeneous texture, commonly were made by masonry technique. Generally 1 or 2 storey houses with courtyards, service spaces such as wide entrance doors, barn, store, warehouse, bakery, hayloft, woodshed and coop, common street ovens which is open to the public within the districts, fountains (wall/square), lack of or shortage of the window openings to the outside world, designing of the real life area on the first floor of the houses, sofa and iwan (eyvan) designs in rooms constitute the architectural identity of the settlement. In addition to these values, one can see that the ground floors of the houses are generally surrounded by high stone walls. As a building material, the lower floors of the majority 
of the houses are masonry and the upper floors are wooden carcasses. It can be said that the emergence of the rooms in the interior space is formed by the emergence of the self-built street pattern with "cumba"s. All of these properties make a holistic effect on the architectural identity of the settlement and they also give a distinctive identity to the built environment, outer space (Bozoğlu, 1996). In addition to the built environment, these values also constitute to the social fabric of Birgi (Figure 2).
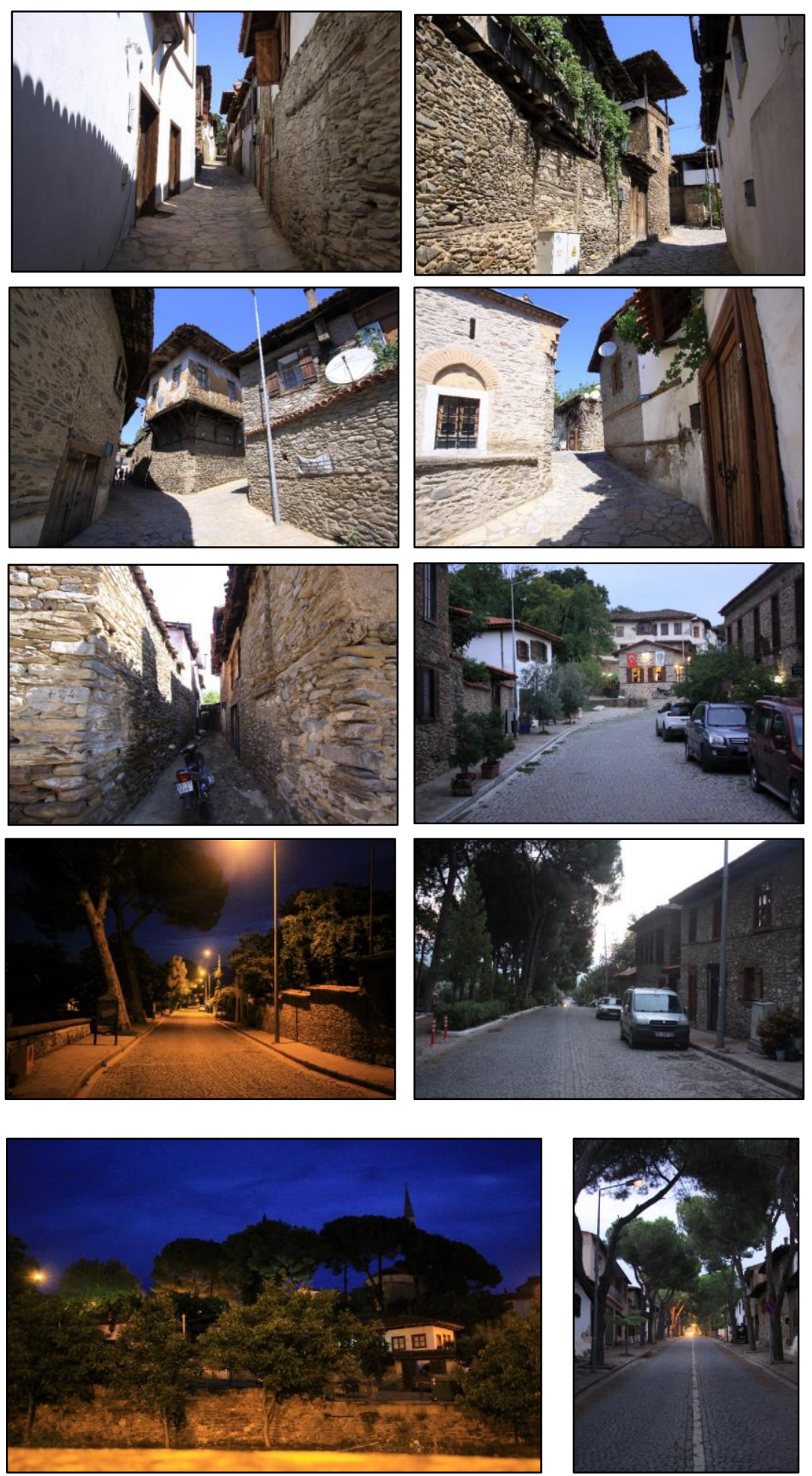

Figure 2. Examples from traditional structures and street patterns of Birgi (K. Topçu, 2018) 
Some symbolic values also have contributional effects on Birgi's whole identity which is formed by its traditional architecture and urban fabric. Birgi has many original fountains which are made by bricks and reusable materials and has the Grand Mosque, which can be considered as a unique example of Turkish wood processing, as a spatial characteristic. Many madrasah and mosque examples were located in the settlement as a reflection of the city identity gained from antiquity. Birgi has many religious buildings and civil architecture examples that symbolize the period of Aydınoğlu Principality and Ottoman Empire (Tanaç, 2001).

There are many important architectural values within the settlement which contribute to the Birgi's own identity. They can be sorted as the followings; Ulu Mosque, Güdük Minare Masjid (Kütük Minareli Mosque), Derviş Ağa Mosque (Çarşı Camii), Karaoğlu Mosque, Aydınoğlu Mehmed Bey Tomb, Sultan Şah Tomb, Kale Madrasah (it is dilapidated and some of the student cells were destroyed), İmam Birgivî Madrasah which is restored and is located at the main square, Derviş Ağa Madrasah (Çukur Madrasah), Çarşı Bath (one part of this bath is grocery), Sasalı Bath, Birgi Şeyh Muhiddin Bath, Bıçakçızade Fountain, Beyler Fountain, Küpuçuranlar (Pankuduz) Tower, Library and Çakırağa Mansion which is well-known as the most important value within the settlement (Figure 3).

Figure 3. Examples of monumentalsymbolic values of Birgi (K. Topçu, 2018)
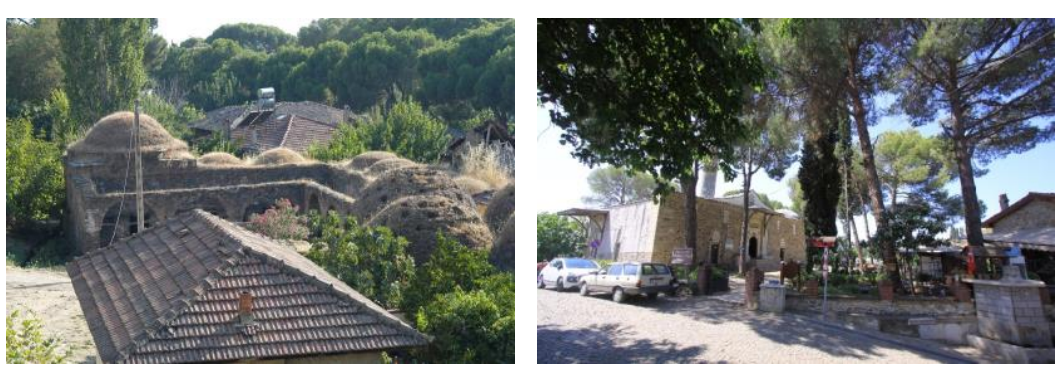

\section{Evaluating Local Identity of Birgi by Natural Environment Aspect; Topographic and Environmental Sources}

In addition to its social, architectural, urban and symbolic formations; rising, descending and valley formations of its topography has also great effects on Birgi' identity. They give Birgi a very special visual identity along with the urban-architectural formations. Birgi, which descends from north to south, has been located in an identifiable area, which is partially fragmented by valleys. Birgi can also be described as a settlement that provides good examples of urban spaces using this special topographical structure correctly (Anonymous, 2001).

Birgi settlement is generally descended from north to south. The decreasing slope to the south and the spreading topography 
reinforce the development of the settlement in this direction. The northward contractionary area and its rising topography in the west can be seen as a threshold to prevent the development of the settlement in these directions.

One of the main determinants of the spatial identity and characteristic of the settlement, which has a large number of underground and surface water resources, is the Birgi River and its bridges. Birgi River feeds the Küçük Menderes River, flow through the settlement and divide the settlement into two parts (There are 5 bridges over the river).

The valley that defines the settlement area to the east of Birgi stream is a very important environmental value with its green texture (Figure 4-5).

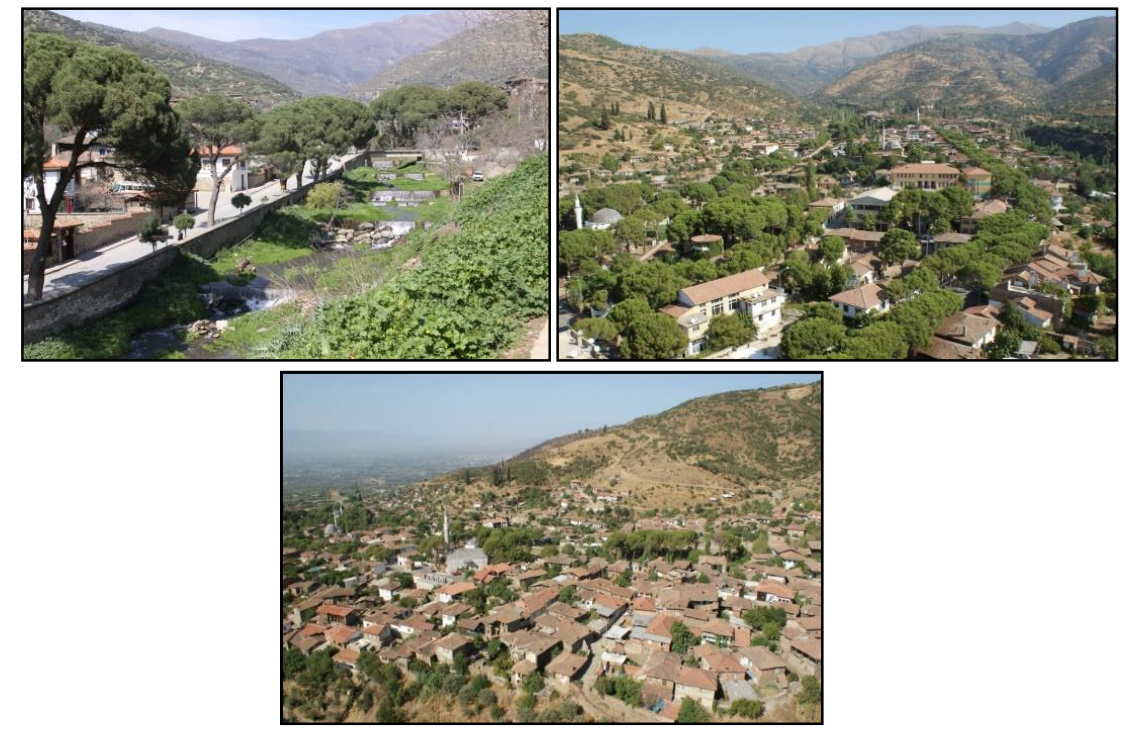

Figure 4. Settlement on the valley (Turkish Aeronautical Association, 2009) and Birgi River (K. Topçu, 2009, 2018) 


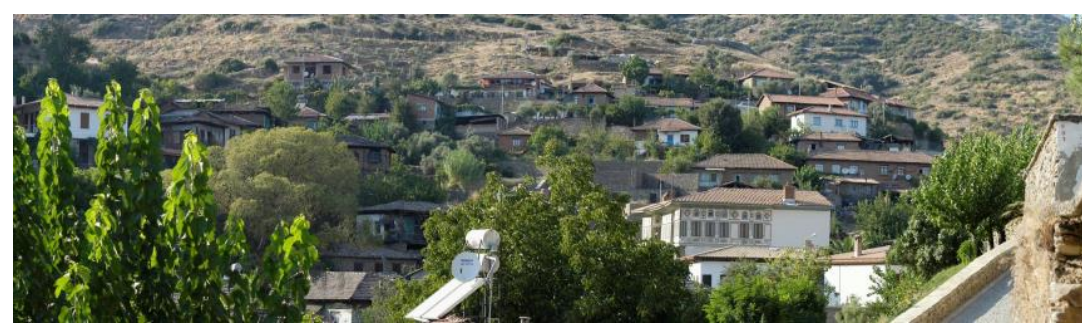

Figure 5. Photographs showing the natural identity of the settlement (K.Topçu, 2018)
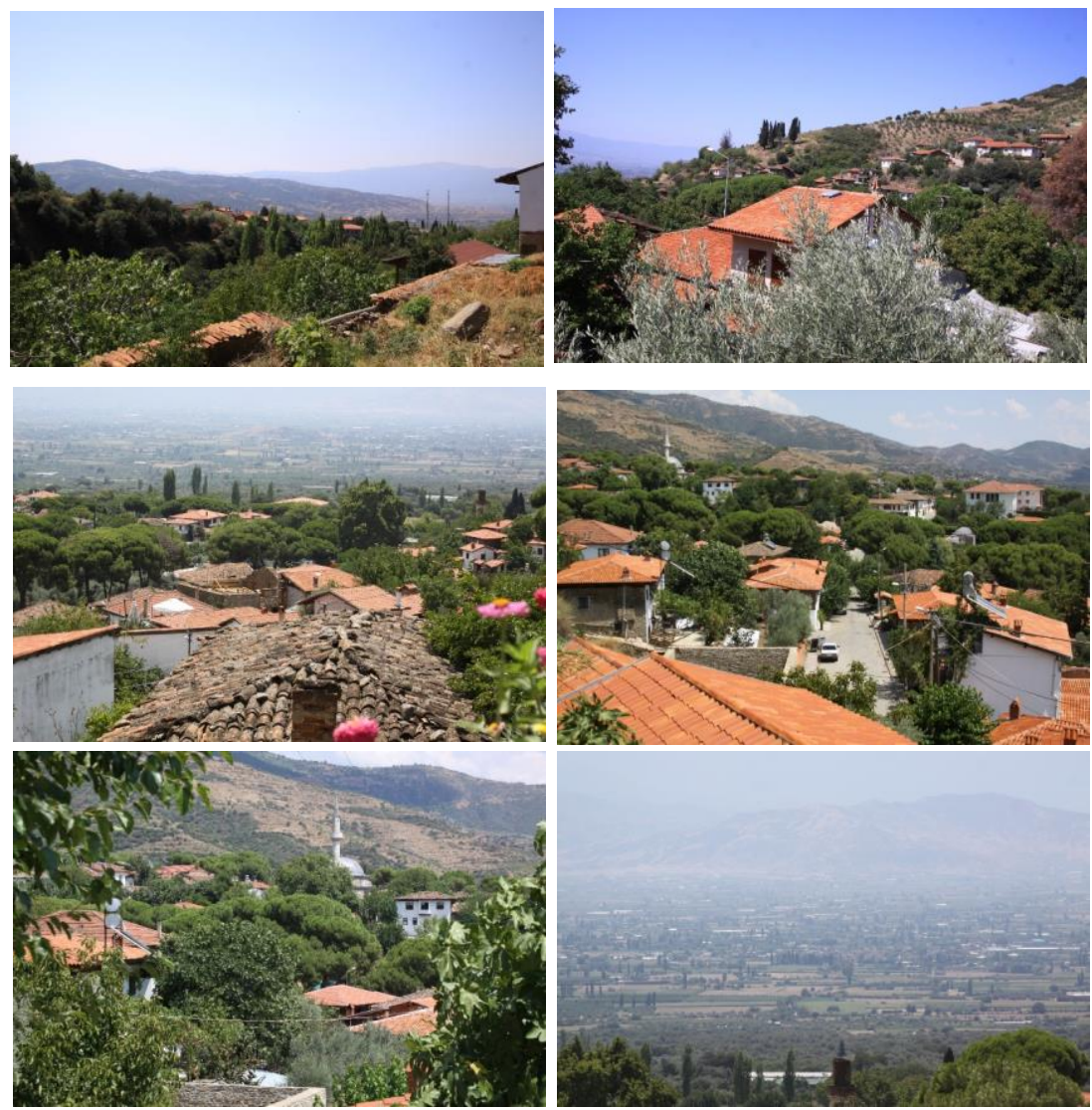

Meticulously preserved of the flora (Eastern Mediterranean flora) which located in the slopes and valleys of the settlement also adds a different value in the formation of Birgi's local identity. The cultivation of a wide variety of vegetables and fruits (especially olive, fig, dry fig, potato etc.) because of its microclimate properties is an indicator of the fertility of the plain. Almost 70\% of Birgi people are engaged in agriculture because of their fertile lands that enable product diversity (Anonymous, 2001).

\section{PROBLEMS AND POTENTIALS OF BIRGI IN TERMS OF LOCAL IDENTITY}

Although Birgi has many strengths, potentials related having an authentic identity (strong social, natural and built environment identity), it has also some problems, weaknesses and threats within its own. 
Determining a Strategy for Sustainable Development of Local Identity: Case of Birgi (İzmir/Turkey)

One of the problems of the area is that many of the historical buildings (especially buildings in Kurtgazi district) cannot have restored because most of the inhabitants are made of elderly people. This situation has compelled conservation and made people moved away from the conscious conservation activities. So, some unconscious additions or attempts on historical and cultural values can be seen within the settlement. On the other hand, we can say that these small-scale changes worked in favor of the settlement to the effect that Birgi could save its own local identity in the holistic scale. This is also related the migration of young people from the settlement or sliding of the qualified working force to the environs. This is one of the leading problem of the area. Inadequate investments in the region accelerate this process. And, also there is not enough socio-cultural areas for the young people.

Despite Birgi has high agricultural potentials, productive soils and appropriate climate that provide product variety (approximately $\% 70$ people of the settlement work in this sector), the settlement cannot evaluate this potential because of being not organized and having not marketing strategies related this sector. We can actually explain this with the migration of young population to the environs on account of insufficient employment opportunities that the settlement offers. Accordingly, most of the population is formed by elderly people. Therefore, it seems rather important for sustaining local identity of Birgi that the migrated young population should be regained because of supporting the economy of Birgi. In recent years, state support can be seen for the rural developments. Therefore, this situation can be an important opportunity for the settlement. Presence of local bazaars and existence of food and beverage companies serving local food in the settlement can be great opportunities in this point for developing slow strategies in the fast life. Thus, the most appropriate strategy for this can be considered as 'Cittaslow' movement. Cittaslow (slow city movement) ${ }^{1}$ approach can be considered as an alternative holistic and positive place-based solution, more human, environmentally correct and sensible for the present and future generations, provided as an answer to the problem of sustaining local identity. This movement, an organized international network of small cities, is attempting to preserve each urban area's own unique characteristics, historical context, local resources, economic \& cultural strengths (Mayer\& Knox, 2006; Radstrom, 2011) and built around the desire to provide a high quality of life for its residents and visitors. In this way, it increases competition by using city's identity and local values. Additionally, by regaining the young population, some historical
1 This movement founded in Italy in 1999 by Paolo Saturnini in order to stop the trend of people moving to bigger cities and to address the 'slow food' philosophy in their urban design, urban policy and planning (Miele, 2008; Radstrom, 2011). Slow Food was introduced as a way of protecting local produce, traditional cuisine and the related cultural connection. It originally began due to the increasing prevalence of fast food restaurants in Italian cities and towns (Radstrom, 2011). From that on the network is proliferating in many other countries, in Europe and in other continents. While there were about 100 slow cities in 2007 now there are 228 cities in 30 countries around the world (URL 2). 
buildings which are in bad conditions could be gained to the Birgi's economy by functioning them by its own.

Accordingly, insufficient technical staff and budget for the restoration of structures that have to be conserved is also one of the leading problems of the area. Of course, the lack of interest of authorized administrations in this point is effective in the process.

It is observed that architectural and urban pattern of the settlement and environmental, natural and topographic data are supportive for possible alternative tourism potentials (i.e. cultural tourism, natural tourism, agro-tourism, sport tourism, highland tourism, and religious tourism). The settlement has many touristic attractors. These attractors can support some activities within the settlement during the year. (i.e. photo safari, botanical tours, paragliding, caving, angling, water sports, trekking, bicycle tours, etc.). When considering the development of the understanding of natural and cultural tourism instead of seasand-sun tourism and the increased interest of local tourists to the region in recent years, these above mentioned potentials also give Birgi a great opportunity for developing alternative tourism strategies for the settlement. But, in this scope, there is a need for developing advertising/marketing strategies for Birgi. It can be said that, the necessity of these strategies is actually in a direct proportion with the difficulty of access to the settlement on account of topographical thresholds. This situation also provides Birgi to sustain and conserve its own character and identity. On the other hand, this provides Birgi having low touristic image and inadequate investments in its vicinity.

When we take into consideration the alternative tourism potentials that can be developed, existing various festivals and activities could be an important input for the advertising strategies. For instance, Mimar Sinan Fine Arts University organizes some workshops, summer schools for educational purposes in Birgi since 2000. In the scope of these kinds of studies, the students of architecture, urban planning, restoration and painting have worked on some surveys and silhouette works related the streets and structures of the Birgi. The students of painting department drew wall paintings in the Birgi streets by using local specific figures within a specific composition. These efforts are very important efforts for sustaining the visual-spatial quality, local identity of the settlement as much as announcing its name. However, in this point, it is obvious that accommodation capacity of the settlement is rather insufficient.

The people of Birgi is hospitable to local and foreign tourists, open minded to new ideas, thoughts and movements. This situation 
seems us to be an important potential for public participation in order to sustain the local identity.

Having renewable energy resources (such as wind, sun) are another opportunities for the settlement. When we take into consideration the southwesters and duration of sunshine (yearly average duration: 8.02 hours), we can say that Birgi has a potential for energy production and has a capability to do it by itself.

Additionally, silk production which exist in the 17th century in the settlement but degreased in the length of time can also be evaluated as an important economic potential for Birgi's local identity.

Finally, besides the settlement offers many strengths and opportunities, it has also many weaknesses and threats (Table 2). The important thing is using the strengths, eliminating the weaknesses, obtaining the opportunities and eliminating the threats. By doing this, we should able to sustain the local identity of the settlement, Birgi.

\section{METHOD}

In this study, to develop appropriate strategies and prioritize them for sustaining Birgi's local identity, as mentioned before, 'A'WOT' analysis was used. This method, which is the combination of SWOT analysis and Analytical Hierarchy Process Technique (AHP), systematically evaluates, quantifies and prioritizes the SWOT factors (strengths, weaknesses, opportunities and threats) based on pairwise comparisons. In this way, this method let the SWOT factors not only be the linguistic data (Saaty, 1994, 2005; Kurtilla et al., 2000; Kangas et al., 2001). In other words, AHP assists in carrying out SWOT more analytically. So that alternative strategic decisions, the choice alternatives can be prioritized with respect to the strategic choice situation as a whole. The aim in applying hybrid method ( $A^{\prime}$ WOT analysis) is to improve the quantitative information basis of strategic planning processes (Kangas et.al. 2001).

In SWOT analysis, the most important internal and external factors for the city's future are grouped into four categories; Strengths, Weaknesses, Opportunities and Threats. By applying SWOT in a strategic planning process, the aim is usually to develop and adopt a strategy resulting in a good fit between these internal and external factors. Although the SWOT analysis successfully explores the factors, individual factors are usually described very generally. If it can be used in a more convenient way, SWOT analysis can provide a basis for the formulation of successful strategies. This can be achieved by increasing the strengths, 
degreasing the weaknesses, benefiting from the opportunities and abstaining from the threats. However, SWOT includes no means of analytically determining the importance of factors and it easily remains at the level of only pinpointing and listing the factors (Kangas et al., 2001; Yllmaz et.al. 2009). This situation generates a need for using SWOT analysis with a more effective tool (Yılmaz et.al. 2009, Yenice, 2014). In this context, to supply the deficiency of SWOT analysis, there is an approach on the literature called 'A'WOT Analysis'.

A'WOT analysis proceeds as follows and the process given below was used in this study;

1. SWOT analysis is carried out.

2. Pairwise comparisons between the SWOT factors are carried out separately within each SWOT group (which of the two factors compared is more important and how much more important) with the aid of Saaty scale (Table 1). With these comparisons as the input, the mutual priorities of the factors are computed. Pairwise comparisons were graded by a total of 35 urban planners/urban planner candidates in this study.

3. The mutual importance of the SWOT groups is determined.

4. The strategy alternatives are evaluated with respect to each SWOT factor as in the AHP.

5. Global priorities are calculated for the strategy alternatives in accordance with the general A'WOT decision hierarchy (Kangas et. al., 2001; Nastase and Kajanus, 2008).

Table 1. Relative importance scale (According to Saaty $(1994,2005)$ )

\begin{tabular}{cll}
\hline $\begin{array}{c}\text { Intensity of } \\
\text { importance }\end{array}$ & Definition & \multicolumn{1}{c}{ Explanation } \\
\hline 1 & Equal importance & $\begin{array}{l}\text { Two activities contribute equally to the } \\
\text { objective }\end{array}$ \\
\hline 3 & Moderate importance & $\begin{array}{l}\text { Experience and judgment slightly } \\
\text { favor one activity over other }\end{array}$ \\
\hline 5 & Strong importance & $\begin{array}{l}\text { Experience and judgment strongly } \\
\text { favor one activity over other }\end{array}$ \\
\hline 7 & Very strong or & $\begin{array}{l}\text { An activity is strongly favored and its } \\
\text { dominance is demonstrated in } \\
\text { practice }\end{array}$ \\
\hline 9 & Extreme importance & $\begin{array}{l}\text { The evidence favoring one activity } \\
\text { over another is of the highest possible } \\
\text { order }\end{array}$ \\
\hline $2,4,6,8$ & Intermediate values & When a compromise needed \\
\hline
\end{tabular}

There are different application areas of A'WOT Analysis on literature (Kurttila et. al., 2000; Pesonen et.al., 2001; Steward et.al., 2002; Kajanus et.al., 2004; Masozera et.al., 2004; Shrestha et.al., 2004; Leskinen et.al., 2006; Shinno et.al., 2006, Yenice, 2014). In this study, A'WOT analysis was used in an urban area 
different from the other studies to produce alternative development strategies and to choose the best among them.

\section{FINDINGS}

\section{SWOT Analysis of Birgi}

In decision-making process, firstly, there is a need to determine the SWOT factors of the sample area (Birgi) which is the first stage of A'WOT analysis. While determining these factors, according to Saaty scale (Table 1), it is needed that the number of factors cannot exceed nine factors ${ }^{2}$. From the findings of local identity values, problems and potentials of Birgi which were assessed above, SWOT analysis of the settlement can be developed like below (Table 2).

Table 2. SWOT Analysis of Birgi

\begin{tabular}{|c|c|}
\hline STRENGTHS & WEAKNESSES \\
\hline $\begin{array}{l}\text { S1- Strong natural beauty (forest areas which } \\
\text { have nectar flowers like chestnut, linden tree and } \\
\text { having water resources etc.) } \\
\text { S2- Conservation of traditional lifestyle and } \\
\text { social pattern } \\
\text { S3- Productive soils that provide product variety } \\
\text { S4- Having strong historical and archeological } \\
\text { heritage (having authentic architectural pattern } \\
\text { and monumental structures) } \\
\text { S5- Hospitability of the people. Most of them are } \\
\text { hospitable to new ideas } \\
\text { S6- Hosting festivals, summer schools, } \\
\text { workshops and various activities in it } \\
\text { S7- Having many touristic attractors (such as } \\
\text { highland tourism, photo safari, botanical tours, } \\
\text { paragliding, caving, angling, water sports, } \\
\text { trekking, bicycle tours, having religious tourism } \\
\text { potential) } \\
\text { S8-Sensitive approach of conservation } \\
\text { S9- Having traditional handicrafts (like silk } \\
\text { handlooms) }\end{array}$ & $\begin{array}{l}\text { W1- Lack of advertising and marketing } \\
\text { strategies of the settlement } \\
\text { W2- Lack of organization on evaluating } \\
\text { and marketing the crops. Having not using } \\
\text { the existing agricultural potentials } \\
\text { efficiently } \\
\text { W3- Dilapidation of some historical and } \\
\text { cultural values rapidly because of the } \\
\text { physical impossibilities (generally elderly } \\
\text { people are living) } \\
\text { W4-Insufficiency of accommodation } \\
\text { W5- Insufficient technical staff and budget } \\
\text { for the restoration of structures that have } \\
\text { to be conserved, Lack of interest of } \\
\text { authorized administrations. } \\
\text { W6- Some unconscious additions or } \\
\text { attempts on historical and cultural values } \\
\text { W7- Lack of qualified workforce } \\
\text { W8- Lack of socio-cultural areas }\end{array}$ \\
\hline $\begin{array}{l}\text { OPPORTUNITIES } \\
\text { 01- Appropriate climate that increases } \\
\text { agricultural productivity } \\
\text { O2-Development of the understanding of tourism } \\
\text { related natural and cultural heritage. Offering } \\
\text { high alternative tourism potentials. } \\
\text { 03- Increased interest of local tourists in the } \\
\text { region } \\
\text { 04- Providing state support in rural development } \\
\text { in recent years } \\
\text { 05- Weak transportation linkages that allow the } \\
\text { urban pattern to be saved } \\
\text { 06- Being in the limelight of non-governmental } \\
\text { organizations (NG0) (Historical Cities Union } \\
\text { provides opportunities on behalf of citizens and } \\
\text { Çekül Foundation supports the restoration } \\
\text { projects in this vicinity) sun) } \\
\text { 07- Allowance of activities during the year. } \\
\text { 08- Having renewable energy resources (such as } \\
\text { wind, } \\
\text { 09- Presence of local bazaars and existence of } \\
\text { food and beverage companies serving local food. }\end{array}$ & $\begin{array}{l}\text { THREATS } \\
\text { T1-Possible natural hazards such as } \\
\text { earthquakes, floods } \\
\text { T2-Migration of young people from the } \\
\text { settlement, sliding of the qualified working } \\
\text { force to the environs } \\
\text { T3- Weak transportation linkages with the } \\
\text { environs } \\
\text { T4- Inadequate investment in the region } \\
\text { T5- Low touristic image }\end{array}$ \\
\hline
\end{tabular}

${ }^{2}$ Based on the principle that the human brain can compare $7 \pm 2$ elements at the same time (Schomoldt et al., 1995), the number of factors in each Swot group should not be more than 9 . 


\section{A'WOT Analysis of Birgi}

Pairwise comparisons between SWOT factors and groups constitute the second stage of the study. Pairwise comparisons between the SWOT factors in this study are carried out separately within each SWOT group (which of the two factors compared is more important and how much more important) with the aid of Saaty scale (Table 1). With these comparisons as the input, the mutual priorities of the factors are computed. Gradings were made by the total of 35 urban planners \& urban planner candidates in this study. The results of the analysis; local priority values of each SWOT factors and global priority values of each SWOT groups are given below (Table 3).

Table 3. Local and global priority values (weights) of SWOT factors

\begin{tabular}{|c|c|c|c|c|c|}
\hline 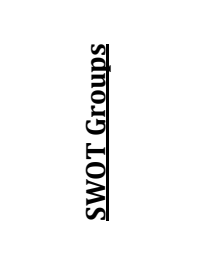 & 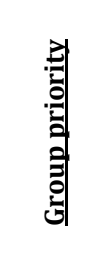 & 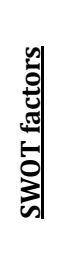 & 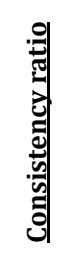 & 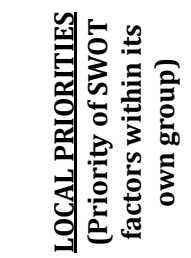 & 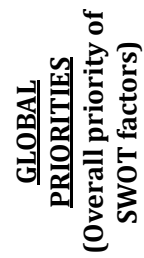 \\
\hline \multirow{9}{*}{ Strengths } & \multirow{9}{*}{$\underline{0,564}$} & S1 & \multirow{9}{*}{0,05} & 0,135 & 0,076 \\
\hline & & S2 & & 0,117 & 0,066 \\
\hline & & S3 & & 0,136 & 0,077 \\
\hline & & $\underline{\text { S4 }}$ & & $\underline{0,175}$ & $\underline{0,099}$ \\
\hline & & S5 & & 0,083 & 0,047 \\
\hline & & S6 & & 0,115 & 0,065 \\
\hline & & S7 & & 0,124 & 0,070 \\
\hline & & S8 & & 0,060 & 0,034 \\
\hline & & S9 & & 0,055 & 0,031 \\
\hline \multirow{8}{*}{ Weaknesses } & \multirow{8}{*}{0,126} & $\underline{\text { W1 }}$ & \multirow{8}{*}{0,05} & $\underline{0,226}$ & $\underline{0,028}$ \\
\hline & & W2 & & 0,211 & 0,027 \\
\hline & & W3 & & 0,153 & 0,019 \\
\hline & & W4 & & 0,122 & 0,015 \\
\hline & & W5 & & 0,078 & 0,010 \\
\hline & & W6 & & 0,081 & 0,010 \\
\hline & & W7 & & 0,095 & 0,012 \\
\hline & & W8 & & 0,034 & 0,004 \\
\hline \multirow{9}{*}{ Opportunities } & \multirow{9}{*}{0,280} & $\underline{01}$ & \multirow{9}{*}{0,09} & $\underline{0,176}$ & $\underline{0,049}$ \\
\hline & & 02 & & 0,164 & 0,046 \\
\hline & & 03 & & 0,110 & 0,031 \\
\hline & & 04 & & 0,119 & 0,033 \\
\hline & & 05 & & 0,066 & 0,019 \\
\hline & & 06 & & 0,072 & 0,020 \\
\hline & & 07 & & 0,101 & 0,028 \\
\hline & & 08 & & 0,073 & 0,020 \\
\hline & & 09 & & 0,119 & 0,033 \\
\hline \multirow{5}{*}{ Threats } & 0,031 & T1 & \multirow{5}{*}{0,08} & 0,180 & 0,006 \\
\hline & & $\underline{\mathbf{T} 2}$ & & $\underline{0,265}$ & $\underline{0,008}$ \\
\hline & & T3 & & 0,232 & 0,007 \\
\hline & & $\mathrm{T} 4$ & & 0,226 & 0,007 \\
\hline & & T5 & & 0,096 & 0,003 \\
\hline
\end{tabular}

Note

-The consistency ratio of the comparisons between four SWOT groups is 0.24 .

-The bold numbers indicate the most significant factors. 
According to the derived results, the strengths of the settlement are stronger compared with the other groups (group priority: 0,564). Among the strengths factors, the S4 factor (having strong historical and archeological heritage-having authentic architectural pattern and monumental structures) is the strongest factor with the values of 0,175 (local priority) and 0,099 (global priority). Lack of advertising and marketing strategies of the settlement is the weakest factor among the other weaknesses factors (W1 local priority: 0,226; W1 global priority: 0,028). Appropriate climate that increases agricultural productivity constitutes the top priority among the opportunities group with the values of 0,176 (local priority) and 0,049 (global priority). And, the migration of young people from the settlement, sliding of the qualified working force to the environs is the most threatening factor of the settlement (0,265-local priority and 0,008-global priority). The following priorities can be seen on the table above. (Table 3).

\section{Developing and Prioritizing Possible Strategies for Birgi}

The third stage of the analysis, TOWS matrix (Weihrich, 1982) was formulated according to SWOT factors which have the highest prioritization values from each SWOT groups. These values can be seen in the Table 3. Kurttilla et al. (2000) stated that strategy alternatives should be determined in a way to cover SWOT factors with the greatest weight. On this stage, by examining the possible scenarios, it was tried to determine the strategies by using the strong priority of the strengths, eliminating the weakness, obtaining the opportunity and eliminating the threat.

In this study, the first four prioritized factors of all SWOT groups were taken into consideration to determine the strategies. However, while producing planning strategies, not all of the four prioritized factors were used within each SWOT groups. The factors that could be related to the planning strategy were chosen among the priority factors. Through TOWS matrix, prioritized possible strategies were developed like below on the basis of sustainability (Table 4). After producing planning strategies, to determine the priorities of the strategies, 5 expert opinions were received by using the same questionnaire base which was used before for the factor priorities. And, the results were given in the Table 5.

According to Table 5, among the four alternative strategies, it was seen that the first strategy (SO Strategy-Entering to Slow City Movement) has the highest priority for the sustainability of Birgi's local identity. 
Table 4. TOWS Matrix for Birgi - produced alternative strategies for 'Birgi' according to priority values (from Weihrich, 1982)

\begin{tabular}{|c|c|c|}
\hline TOWS MATRIX & $\begin{array}{l}\text { Prioritized strengths } \\
\text { S4- Having strong historical } \\
\text { and archeological heritage } \\
\text { (having authentic } \\
\text { architectural pattern and } \\
\text { monumental structures) } \\
\text { S3- Productive soils that } \\
\text { provide product variety } \\
\text { S1- Strong natural beauty } \\
\text { (forest areas which have } \\
\text { nectar flowers like chestnut, } \\
\text { linden tree and having water } \\
\text { resources etc.) } \\
\text { S7- Having many touristic } \\
\text { attractors (such as highland } \\
\text { tourism, photo safari, } \\
\text { botanical tours, paragliding, } \\
\text { caving, angling, water sports, } \\
\text { trekking, bicycle tours, having } \\
\text { religious tourism potential) }\end{array}$ & $\begin{array}{l}\text { Prioritized weaknesses } \\
\text { W1- Lack of advertising } \\
\text { and marketing strategies } \\
\text { of the settlement } \\
\text { W2- Lack of organization } \\
\text { on evaluating and } \\
\text { marketing the crops. } \\
\text { Having not using the } \\
\text { existing agricultural } \\
\text { potentials efficiently } \\
\text { W3- Dilapidation of some } \\
\text { historical and cultural } \\
\text { values rapidly because of } \\
\text { the physical } \\
\text { impossibilities (generally } \\
\text { elderly people are living) } \\
\text { W4-Insufficiency of } \\
\text { accommodation }\end{array}$ \\
\hline $\begin{array}{l}\text { Prioritized opportunities } \\
\text { 01- Appropriate climate } \\
\text { that increases agricultural } \\
\text { productivity } \\
\text { 02-Development of the } \\
\text { understanding of tourism } \\
\text { related natural and cultural } \\
\text { heritage. Offering high } \\
\text { alternative tourism } \\
\text { potentials. } \\
\text { 04- Providing state support } \\
\text { in rural development in } \\
\text { recent years } \\
\text { 09- Presence of local } \\
\text { bazaars and existence of } \\
\text { food and beverage } \\
\text { companies serving local } \\
\text { food. } \\
\text { 03- Increased interest of } \\
\text { local tourists in the region }\end{array}$ & $\begin{array}{c}\text { SO STRATEGY } \\
\frac{\text { 'Entering to 'Slow City }}{\underline{\text { Movement' }}} \\
\text { Strategy } 1 \\
(S 4, S 3, S 1,01,02,09,03)\end{array}$ & $\begin{array}{c}\text { WO STRATEGY } \\
\frac{\text { Increasing in }}{\text { agricultural }} \\
\begin{array}{c}\text { production, its } \\
\text { organization and }\end{array} \\
\text { marketing' } \\
\text { Strategy } 2 \\
(01,04,09, W 1, W 2)\end{array}$ \\
\hline $\begin{array}{l}\text { Prioritized threats } \\
\text { T2-Migration of young } \\
\text { people from the settlement, } \\
\text { sliding of the qualified } \\
\text { working force to the } \\
\text { environs } \\
\text { T3- Weak transportation } \\
\text { linkages with the environs } \\
\text { T4- Inadequate investment } \\
\text { in the region } \\
\text { T1-Possible natural hazards } \\
\text { such as earthquakes, floods }\end{array}$ & $\begin{array}{c}\text { ST STRATEGY } \\
\frac{\text { 'Development of Alternative }}{\text { Tourism Sector' }} \\
\text { Strategy } 3 \\
(S 4, S 3, S 1, S 7, T 2, T 3, T 4)\end{array}$ & $\begin{array}{c}\text { WT STRATEGY } \\
\frac{\text { Becoming a cultural }}{\text { center focused on }} \\
\frac{\text { artistic activities }}{\text { Strategy } 4} \\
(W 1, W 3, W 4, T 2, T 3, T 4)\end{array}$ \\
\hline
\end{tabular}

Table 5. Prioritization of the alternative strategies

\begin{tabular}{|l|l|l|}
\hline & Produced Strategies for Birgi & \\
\hline STR1 & $\underline{\text { Entering to 'Slow City Movement' }}$ & $\underline{\mathbf{0 , 4 2 5}}$ \\
\hline STR2 & Increasing in agricultural production, its organization and marketing & 0,175 \\
\hline STR3 & Development of Alternative Tourism Sector & 0,335 \\
\hline STR4 & Becoming a cultural center focused on artistic activities & 0,065 \\
\hline
\end{tabular}




\section{CONCLUSION}

Birgi, which managed to hide itself from today's environment in which all the values are upside down, was able to protect its original identity except invasions, earthquakes and floods. As one of the few settlements that protect traditional dwellings, monumental structures and nature triads, Birgi reflects an authentic identity and appears to be capable of achieving a strong chance. It also has a different meaning with its houses which bring interesting views to interesting streets.

Today, along with its natural structure, social and cultural life and urban texture shaped by historical cultural layers, it has a strong and unique local identity that keeps alive the concept of 'sense of place'. Sustaining and maintaining this situation is very important in terms of protecting the collective memory. From this important point, within the scope of the study, among the different strategies based on sustainability concept developed for Birgi settlement, it is evident that the "Entering to Slow City Movement" strategy has a priority for sustaining Birgi's local identity.

It is obvious that the sustainability and livability of authentic settlements which embody strong urban identities is rather important and they should be undertaken rather carefully (Radstrom, 2011). In this point, Cittaslow (slow city movement) approach can be considered as an alternative holistic and positive place-based solution, more human, environmentally correct and sensible for the present and future generations, provided as an answer to the problem of sustaining local identity.

In addition, this is a movement which respects 'small realities' in a more and more global connected world (Radstrom, 2011) and can be considered as a positive attitude towards the similar cities which lose its local properties and an urbanization politics which put forward traditional life styles, preserve local life style, consume local products versus 'fast food' culture (Uslu, 2009; Keskin, 2012).

In recent years, cities are in search for new ways to promote themselves because of being updated continuously to compete with the other cities. In that sense, cities develop strategies to support, to `sell and advertise them within the global market. One of the ways for cities which do not want to be one of the homogeneous places or want to be in the world stage by preserving its local identity and properties is to participate in to this international network. However, this situation is only for the cities which have the population under 50.000. Today, the network is proliferating in many countries, including Europe and other continents. While there were about 100 slow cities in 2007, 
now there are 228 cities in 30 countries all around the world (URL 2). In Turkey, today, there are 11 slow cities from different parts of the country such as Seferihisar (İzmir), Gökçeada (Çanakkale), Taraklı (Sakarya), Akyaka (Muğla), Halfeti (Urfa), Perşembe (Ordu), Şavşat (Artvin), Vize (Kırklareli), Yalvaç (Isparta), Yenipazar (Aydın) and Uzundere (Erzurum). Birgi can also be the other slow city candidate in Turkey with its strong local identity.

For participating in Cittaslow movement, Birgi should fulfill some necessities. For this, it is important to be taken into account the followings; 1. Environment Politics, 2. Infrastructure Politics, 3. Quality of Urban Life Politics, 4. Policies on agricultural, touristic, artisans and craftsmen, 5. Plans for hospitality, awareness and education, 6. Social harmony, 7. Partnerships. When we consider all of the strengths and opportunities of the settlement, there is no reason for fulfilling the above necessities and participating in the 'Cittaslow' movement (slow city movement).

\section{REFERENCES}

Abel, C. (1997). Architecture and Identity, Towards a Global EcoCulture, Architectural Press.

Altınoluk, Ü. (1997). Su Şehri Birgi, İlgi dergisi, sayı:89, sf. 3-7, İstanbul.

Altınoluk, Ü. (1998). Selvi ve Birgi, İlgi dergisi, sf.14, İstanbul.

Altınoluk, Ü. (2001). The Field Studies in Birgi: The Example of Industrial Archeology, Traditional Environments in a New Millennium, Amasya.

Altınoluk, Ü. (2007). Geleneksel Kent Dokusu Birgi, Ege yayınları, İstanbul.

Aly, S.S.A. (2011). Modernization and Regionalism: Approaches for Sustainable Revival of Local Urban Identity, Procedia Engineering 21, 503-512, Elsevier.

Anonymous, (2001). Birgi, Kültür Bakanlığı yayınları, sf.3. Ankara. Appleyard, D. Jacobs, A. (1982). Toward an Urban Design Manifesto, IURD Working Paper 384., University of California, Berkeley.

Ayan, M. (1985). Konut Alanları Tasarım Illkesi, Kent Koop. Yay. 52, Ankara.

Bozoğlu, T. (1996). İzmir İlinde Bir Kültür Merkezi: Birgi, Arkitekt Dergisi, sayı 440, sf. 86-95.

Clare, C. M. \& Francis, C. (1997). People Places: Design Guidelines for Urban Open Space, Wiley; 2nd Edition.

Deniz, K. (2004). Konya'da Farklı Üç Kentsel Mekanda Kent Kimliği Üzerine Bir Araştırma, Basılmamış Yüksek Lisans Tezi, Selçuk Ünv., Fen Bilimleri Ens., Konya. 
Determining a Strategy for Sustainable Development of Local

Identity: Case of Birgi (İzmir/Turkey)

Eruzun, C. (2000). Türkiye'de katılımcı korumaya bir örnek Birgi Yaz Okulu modeli, Tasarım+Kuram, sayı.2, sf.13-26.

Featherstone, M. (1993). Global and Local Cultures, Mapping the Futures: Local Cultures, Global Change (eds. John Bird et al.), 169-87. London: Routledge.

Gençsoylu, Z. (2009). 17 ve 18. Yüzyıllarda Birgi Kazası, Adnan Menderes Ünv., Sosyal Bilimler Ens., Yüksek Lisans Tezi, Aydin.

Hough, M. (1990). Out of Place, Yale Unv. Pres.

Kajanus, M. Kangas, J. and Kurttila, M. (2004). The Use of Value Focused Thinking and A'WOT Hybrid Method in Tourism Management, Tourism Management, Volume: 25, pp: 499506.

Kangas, J. Pesonen, M. Kurttila, M. \& Kajanus, M. (2001). A'WOT: Integrating the AHP with SWOT Analysis, ISAHP 2001, Berne, Switzerland, pp. 189-198.

Keskin, E. B. (2012). Sürdürülebilir Kent Kavramına Farklı Bir Bakış: Yavaş Şehirler (Cittaslow), Paradoks Ekonomi, Sosyoloji ve Politika Dergisi, cilt: 8, sayı: 1, 81-99.

Knox, P.L. (2005). Creating Ordinary Places: Slow Cities in a Fast World, Journal of Urban Design, vol.10, no.1, pp. 1-11, Routledge.

Kotler, P. and Gertner, D. (2002). Country as a Brand, Product and Beyond: A Place Marketing and Brand Management Perspective, Journal of Brand Management, vol. 9, no. 4-5, pp. 249-261.

Kurttila, M. Pesonen, M. Kangas, J. and Kajanus, M. (2000). Utilizing the Analytic Hierarchy Process (AHP) in SWOT Analysis - A Hybrid Method and Its Application to a Forest-Certification Case, Forest Policy and Economics, v: 1, pp: 41-52.

Leskinen, L. A. Leskinen, P. Kurttila, M. Kangas, J. and Kajanus, M. (2006). Adopting Modern Strategic Decision Support Tools in the Participatory Strategy Process - A Case Study of a Forest Research Station, Forest Policy and Economics, Volume: 8, pp: 267-278.

Lynch, K. (1960). The Image of the City, MIT press.

Lynch, K. (1981). A Theory of Good City Form, MIT press, Cambridge, MA.

Masozera, M. K. Alavalapati, J. R. R. Jacobson, S. K. and Shrestha, R. K. (2006). Assessing the Suitability of Community-Based Management for the Nyungwe Forest Reserve, Ruanda, Forest Policy and Economics, v.8, pp: 206-216.

Mayer, H. Knox, P. L. (2006). Slow Cities: Sustainable Places in a Fast World, Journal of Urban Affairs, v.28. n.4. p.321-334. ISSN: 0735-2166.

Miele, M. (2008). Cittaslow: Producing Slowness against the Fast Life, Space and Policy, vol.12, no.1, pp. 135-156, Routledge. 
Montgomery, J. (1998). Making a City: Urbanity/Vitality \& Urban Design, Journal of Urban Design. vol.3. no.1.

Nastase, C. Kajanus, M. (2008). The Role of the Universities in a Regional Innovation System - A Comparative A'wot Analysis, Interferente Economice, n.23., pp. 219-224.

Ocakçı, M. (1993). Şehir Kimliği ve Çevre İlişkileri, İ.T.Ü Mimarlık Fak. Şehir ve Bölge Planlama Bölümü Ders Notları, İstanbul.

Ocakçl, M. Southworth, M. (1995). Elements of Urban Identity; the Case of the Beykoz District of Istanbul, IURD, Working Paper 650, Unv. of California, Berkeley.

Oktay, D. (1998). Urban Spatial Patterns and Local Identity: Evaluation in a Cypriot Town, Open House International, vol.23, no.3, p.17-23.

Öngül, Z. (2012). Analysing the City Identity of Nicosia from a Historical Perspective: External Effects, Solutions Proposed, Procedia - Social and Behavioral Sciences, 35, p.284-292.

Pesonen, M. Kurtila, M. Kangas, J. Kajanus, M. and Heinonen, P. (2001). Assessing the Priorities Using A'WOT among Resource Management Strategies at the Finnish Forest and Park Service, Forest Science, v.47, n.4, pp: 534-541.

Pink, S. (2009). Urban Social Movements and Small Places, City, vol.13, n.4, pp. 451-465, Routledge.

Radstrom, S. (2011). Identity: an Introduction and History of Cittaslow, Italian Journal of Planning Practice (IJPP), vol.1, issue.1, p.90-113, ISSN: 2239267X.

Saaty, T.L. (1994). How to Make a Decision: The Analytic Hierarchy Process, Interfaces, vol. 24, no. 6, pp.19-43.

Saaty, T.L. (2005). Theory and Applications of the Analytic Network Process, Pittsburgh, PA: RWS Publications.

Schomoldt, D. L. Peterson, D. L. and Smith, R. L. (1995). The Analytic Hierarchy Process and Participatory Decision Making, Proceedings of the 4th International Symposium on Advanced Technology in Natural Resource Management, (Editors: J. M. Power, M. Strome and T. C. Daniel), pp: 129-143, Bethesda, MD, U.S.A.

Shaftoe H. (2008). Convivial Urban Spaces: Creating Effective Public Spaces, Earthscan publications ltd.

Shinno, H. Yoshioka, H. Marpaung, S. and Hachiga, S. (2006). Quantitative SWOT Analysis on Global Competitiveness of Machine Tool Industry, Journal of Engineering Design, vol.17, n.3, pp: 251-258.

Shrestha, R. K. Alavalapati, J. R. R. and Kalmbacher, R. S. (2004). Exploring the Potential for Silvopasture Adoption in SouthCentral Florida: An Application of SWOT-AHP Method, Agricultural Systems, vol.81, pp: 185-199. 
Determining a Strategy for Sustainable Development of Local

Identity: Case of Birgi (İzmir/Turkey)

Steward, R. Moarmed, S. and Daet, R. (2002). Strategic Implementation of IT/IS Projects in Construction: A Case Study, Automation in Construction, vol. 11, pp: 681-694.

Tanaç, M. (2001). Birgi'nin Yok Olma Nedenlerinin Sosyal ve Fiziksel Boyutu, TAÇ Vakfı 25. Yıl Anı Kitabı, Türkiye'de Risk Altındaki Doğal ve Kültürel Miras, TAÇ Vakfı yayınları, sf. 317-332, İstanbul.

Tekeli, İ. (1990). Bir Kentin Kimliği Üzerine Düşünceler, Antalya Kent Merkezi İçinde Kalekapısı ve Çevresi Kentsel Tasarım Yarışması Notları, Antalya.

Uslu, A. (2009). Sürdürülebilir Yeşil Kent Fikirleri, Örnekleri ve Türkiye İçin Dersler, 21. Uluslararası Yapı ve Yaşam Kongresi Bildiriler Kitabı, Bursa: TMMOB Mimarlar Odası Yayını.

Weihrich, H. (1982), The TOWS Matrix: A Tool for Situational Analysis, Long Range Planning, 15 (2) , 54-66.

Yavuz, B.G. (1980). XIII. ve XIV. Yüzyıllarda Ödemiş Yöresindeki Babalar, Bülten 5, sf.25. Ödemiş.

Yavuz, B.G. (2005). Birgi: Coğrafyası, Halk Bilgisi, Tarihçesi, Tarihi Yerleri, Birgi Kent Kitaplığı, İzmir.

Yenice, M.S. (2014). Konya Tarihi Kent Merkezi İçin Turizm Odaklı Yenileme Stratejileri, Artium, vol.2. no.1, pp. 70-84.

Yılmaz, E. Coşgun, U. Koçak, Z. Ay, Z. Orhan, K.H. (2009). Katılımcı Yaklaşımla Ekoturizm Stratejilerinin Belirlenmesi ve Önceliklendirilmesi: Cehennemdere Vadisi ve Köprülü Kanyon Milli Parkı Örnekleri, Çevre ve Orman Bakanlığı yayın no:386., DOA yayın no:51, Teknik Bülten no.29, ISBN: 978-605-393-055-6, T.C. Çevre ve Orman Bakanlığ Doğu Akdeniz Ormancılık Araştırma Enstitüsü, Tarsus.

URL 1: http://www.nufusune.com

URL 2:Cittaslow official website, http://www.cittaslow.net (2016, 2018).

\section{Resume}

Kadriye (Deniz) Topcu received her BSc degree from Istanbul Technical University, Faculty of Architecture and Department of Urban and Regional Planning in 2001. Her MSc (2004) and PhD (2011) degrees are from Selcuk University, Faculty of Engineering \& Architecture, Department of Urban and Regional Planning. In MSc thesis she studied urban identity \& image concepts, and she continued her academic career with her dissertation relating the concepts of traditional/modern shopping areas and their spatial qualities. Currently, she has been working at Konya Technical University, Faculty of Architecture and Design, Department of Urban and Regional Planning as an Assist. Prof. since 2018. She worked at Selcuk university as a Research Assistant between the years of 2002-2014 and as an Assist. Prof. between 2014-2018. She experienced a post doctoral research as a visiting scholar at the University of California, Berkeley (USA) in 2013-2014 
academic year and studied with Prof. Michael Southworth about POE technique in urban design. Her research interests are Urban Design, Urban Identity \& Image, Urban Environment Psychology, Urban Quality, Urban Aesthetics, Shopping Places and Urban Sociology. She has several courses related her research interests at the university since 2014 . She is married and has two beautiful sons. 